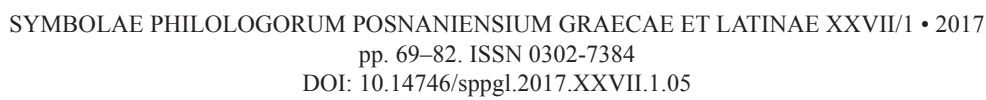

JOANNA PYPŁACZ

Biblioteka Jagiellońska (Sekcja Starych Druków)

al. Mickiewicza 22, 30-059 Kraków

Polska - Poland

\title{
SENECA AND SYNAESTHESIA. THE SENSORY ASPECT OF THE TRAGEDIES
}

ABSTRaCT. Pypłacz Joanna, Seneca and Synaesthesia. The sensory aspect of the tragedies. (Seneka i synestezja. Sensoryczny aspekt tragedii).

The present article discusses selected examples of the poetic means which Seneca uses in order to achieve the effect of synaesthesia in his tragedies. An analysis of these examples reveals that the poet makes the most of the Latin language's semantic and musical potential and in doing so achieves quite spectacular sensory effects.

Keywords: Seneca; tragedy; synaesthesia; alliteration; polysemy; meaning; senses.

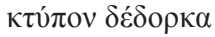

(I can see the noise)

Aeschylus, Seven against Thebes ${ }^{1}$

Les parfums, les couleurs et les sons se répondent. (Perfumes, colours and sounds correspond.)

Charles Baudelaire, Correspondances

Synaesthesia, which is most often associated with modern poets such as the French Symbolists, would also seem to have been a feature of the work of ancient authors. Several articles on the subject were published in the twentieth century ${ }^{2}$ and more recently we have seen the publication of whole books devoted to this particular phenomenon. The first of these collective volumes, entitled Synaesthesia and the Ancient Senses, comprises various articles on synesthetic aspects of ancient literature. ${ }^{3}$ The second bears the title Smell and the Ancient Senses,${ }^{4}$ while the third is entitled Sight and the Ancient Senses. ${ }^{5}$

\footnotetext{
${ }^{1}$ Aesch. Sev. 103.

${ }^{2}$ Segal 1977; Stevens 2008; Rees 1994: 75.

${ }^{3}$ Butler and Purves 2013.

${ }^{4}$ Bradley 2016.

${ }^{5}$ Squire 2016.
} 
To date, scholars have discussed cases of synaesthesia in the works of such poets as Lucretius, Ovid, ${ }^{6}$ Manilius ${ }^{7}$ and Lucan. ${ }^{8}$ Mark Bradley has quoted en passant a fragment of the dubious Hercules Oetaeus as an example of literary synaesthesia (Fleat Alciden caerula Crete, HerO. 1874). ${ }^{9}$ Apart from such random observations, however, it would seem that Seneca's poetry has so far not been examined with reference to this particular literary device - and this despite the fact that the author's rich, 'rhetorical' style makes his work eminently eligible for such an investigation. ${ }^{10}$

Brought up by his father (who was a famous teacher of rhetoric) and endowed with a vivid and even highly graphic imagination, Seneca is known for his expressive, visceral language ${ }^{11}$ and his very extensive vocabulary. As Annette Baertschi has observed, his tragedies "appeal to the rational as well as emotional faculties of the audience. They provide visual and verbal, and cognitive stimuli and lead to learning and philosophical insight through shocking and unsettling closeness." 12 The aim of this article is to determine what literary devices Seneca uses in his tragedies in order to appeal to the audience's sensory imagination and whether or not (and if so, how) he combines them.

\section{CREUSA'S BLUSH}

One of the most common examples of ancient synaesthesia is the Homeric "wine-dark sea" (Hom. Il. 23.143; Hom. Od. 5.132, 5.221, 7.250, 12.388). ${ }^{13}$ The sensory potential of this simple expression is quite remarkable. For some, the association of the sea with wine can be explained by the fact that as the sun sets, the sea often acquires a reddish tint that makes it reminiscent of wine. For others, this similarity is explained by the movement of the sea, which brings to mind the bubbling of wine during fermentation. ${ }^{14}$

Interestingly, in Seneca's tragedies the relationship between colours and liquids is a recurrent motif. Sometimes the attributes of liquids are transferred to colours, as in the following passage:

Ostro sic niveus puniceo color

perfusus rubuit, sic nitidum iubar

\footnotetext{
${ }^{6}$ Bradley 2013: 139.

${ }^{7}$ Volk 2013.

${ }^{8}$ Walter 2013.

${ }^{9}$ Bradley 2013: 132.

${ }^{10}$ Wilson 2010.

${ }^{11}$ Slaney 2016: 237.

${ }^{12}$ Baertschi 2016: 175.

${ }^{13}$ Bradley 2013: 132.

${ }^{14}$ Bradley 2013: 132.
} 
pastor luce nova roscidus aspicit.

(Sen. Med. 99-101)

Such is the blush of snow white colour suffused

by scarlet dye; so the bright dawn rays

are viewed at first light by a shepherd amidst the dew. ${ }^{15}$

The Punic purple ${ }^{16}$ (ostro... puniceo) literally pours over the white skin of the bride. This image is not an invention of Seneca's, as it is also found in Catullus' Epithalamion and Virgil's Aeneid. Here it would seem that Seneca was directly inspired by Virgil's famous description of Lavinia's blush at the sight of her husband-to-be Turnus: ${ }^{17}$

Indum sanguineo veluti violaverit ostro

si quis ebur, aut mixta rubent ubi lilia multa

alba rosa, talis virgo dabat ore colores. (Verg. Aen. 12.67-9)

As when someone stains Indian ivory with crimson dye, or white lilies blush when mingled with many a rose - such hues her maiden features showed. ${ }^{18}$

The word ostrum brings about associations with an oyster and its pale, opalescent shell. The complexion of the Italian princess is thus depicted as being beautifully radiant and shimmering. ${ }^{19}$

"The mingling of white and red in a bride's complexion is - as Boyle has noted - a precursor of disaster." ${ }^{20}$ Indeed, Lavinia's marriage to Turnus - like that of Creusa to Jason - will never take place. Both will end in pain and bloody disaster - in a crime perpetrated by the less fortunate suitor on his luckier rival. In this intertextual scheme, Medea finds herself in a position which is similar to that of Aeneas: she must defeat a rival who enjoys the favours of the person she loves.

Lavinia's blush is ambiguous. On the one hand, it expresses her warm feelings towards Turnus, but on the other hand it has associations with blood (sanguineo ... ostro) as well as the verb violaverit, whose rather sinister-sounding meaning would seem to be a disguised harbinger of the young Rutulian king's violent death by the hand of his victorious rival Aeneas, who will eventually marry Lavinia.

\footnotetext{
${ }^{15}$ Trans. Fitch 2002.

${ }^{16}$ Boyle 2014: 147.

${ }^{17}$ Bellandi 2010. Cf: "uxor in thalamo tibi est, / ore floridulo nitens, / alba parthenice velut / luteumve papaver" (Catull. 61, 185-8). "Now you may come, bridegroom; your wife is in the bride-chamber, shining with flowery face, like a white daisy or yellow poppy" (Trans. Cornish 1913).

${ }^{18}$ Trans. Rushton Fairclough 1918.

${ }^{19}$ Bradley 2013: 134.

${ }^{20}$ Boyle 2014: 147.
} 
Aeneas's plan to become Lavinia's husband - which is a violation of the original promise given to Turnus by King Latinus (the world violaverit may thus also allude to that broken vow) is the result of cool political calculation rather than any ardent feelings towards the princess. Medea, however, is overcome by unhappiness in love, bitterness and wild revenge (saevit infelix amor, 136).

The expressiveness of Virgil's description - which is proportionate to the scale of the emotions involved (Medea's vengeance being much more passionate than Aeneas's ambition) and also to the scale of the disaster (Turnus's death paling in comparison with Creusa's horrible end) - is much less intense than that of Seneca, which has been enhanced by synaesthesia.

In the passage of Medea in question, the blush not only resembles blood because of its particular colour, but actually behaves like blood. The participle perfusus comes from the verb perfundo, whose primary meaning refers to all sorts of liquids which "imbue" some object or are "poured over" it. The changing nature of Creusa's blush reminds the audience of Medea's previous mention of all the blood that she has spilt in the past ("funestum impie / quam saepe fudi sanguinem", 134-5) and also alludes to the poisonous blood of Nessus in which she is going to immerse the bride's garment ("vectoris istic perfidi sanguis inest, / quem Nessus expirans dedit.", 775-6).

By endowing a colour with the properties of a liquid, Seneca achieves an interesting effect. While the mention of redness (puniceo, rubuit, roscidus), whiteness (niveus) and light (nitidum iubar, luce nova) clearly appeals to the sense of sight, the primary meaning of the word ostrum appeals to the audience's sense of taste, as oysters were one of the most popular foods in ancient Rome. Following in the footsteps of Virgil, Seneca achieves an interesting kind of synaesthesia, as the primary meaning always 'shows through' the secondary meaning, thus stimulating the audience's sensory imagination.

\section{TIRESIAS'S BLOOD}

A different instance of synaesthesia - also connected with the motif of blood - is to be found in Seneca's other tragedy Oedipus:

Fata eruantur; si foret viridis mihi

calidusque sanguis, pectore exciperem deum. (Sen. Oed. 297-8)

We must root out what fate has decreed. If my blood were hot and vigorous, I would receive the god into my breast. ${ }^{21}$

Although the adjective viridis - used here in reference to Tiresias's blood also has metaphorical meanings such as 'fresh', 'young' or 'lively', its primary

${ }^{21}$ Trans. Fitch 2004. 
meaning is the colour green. It is used in reference to blood in Pliny the Elder's Naturalis historia ("lacertae viridis sanguis subtritos et hominum et iumentorum pedes sublitus", 30,80) - but there the "green blood" of the lizard is literally and not metaphorically green. ${ }^{22}$

The "green blood" in the passage from Oedipus is therefore a little ambiguous. Thanks to its primary meaning, the adjective viridis - which here obviously denotes vigour and the fast movement of blood - is also strongly associated with a particular colour. Together with the adjective calidus it forms quite an extraordinary pair. The audience can perceive the blood as being both warm and alive ("green") at the same time.

Like the sea-wine metaphor in the Odyssey, the expressive depiction of Tiresias's blood in Seneca's tragedy evokes many associations, as its youthful vitality (compare: primone in aevo viridis an fracto occidit?, Sen. Oed. 775) may result from its rapid flow, its freshness or some other property. Nonetheless, it inevitably evokes automatic associations with the colour green.

In these lines, Seneca offers his audience a rich, synaesthetic experience, appealing to two senses at the same time. Thanks to the adjective calidus, they can "feel" the warmth of Tiresias's blood in their sensory imaginations, while the adjective viridis allows them to imagine the force with which it rushes through blood vessels. At the same time, the inevitable encroachment of the primary meaning of viridis on its secondary meaning results in an additional experience that is 'visual'.

\section{WORDS AS WEAPONS}

Some other interesting cases of the use of synaesthesia in Seneca's tragedies involve the sense of hearing. The first of these is quite remarkable and is to be found in Medea: "Occidimus: aures pepulit hymenaeus meas." (Sen. Med. 116) ("I am finished: the wedding hymn has struck my ears."23) The primary meaning of the verb pello is the action of striking, beating or pushing. Translated literally, this line means: I have died. Hymenaeus has struck / beaten / pushed my ears. Metaphorically, pello also means 'to move' or 'to afflict', which fits in this part of Medea's speech. ${ }^{24}$ A metaphorical translation of the line would therefore read: Hymenaeus has moved / afflicted my ears. Even so, the word pello - which is loaded with synaesthetic potential resulting from its primary meaning (and also from the reduplication at the beginning of the perfect stem) - enhances the expression aures pepulit with an additional synaesthetic quality.

${ }^{22}$ Bradley 2013: 131.

${ }^{23}$ Trans. Fitch 2002.

${ }^{24}$ Cicero uses a similar expression in reference to powerful oratorial subjects: "[...] quod cum animos hominuim aurisque pepulisset" (Cic. Or. I77). Cf. Kent 1910: xlv. 
Line 116 marks the beginning of Medea's long speech, which is her response to the cheerful hymenaeus song of the chorus (lines 56-115). ${ }^{25}$ The highly emotional language she uses is a clear sign of her deep distress. The shock of learning the devastating news that Jason is abandoning her in order to marry Creusa is compared to dying, as the initial occidimus literally means "I have died".

The Hymenaeus sung by the chorus has mentally annihilated Medea, which is why she talks about her "death". At the same time, it is presented as a sort of physical entity that - like some kind of weapon - has physically hurt Medea by striking her ears. On the other hand, Hymenaeus is also the name of the Greek god of marriage. This makes the synaesthetic experience even stronger, as the 'aggressive' song is given an anthropomorphic form because of the association with this minor deity. The audience can therefore imagine the song as a personified oppressor and thus sympathize with the heroine's physical and mental pain. This same expression - aures pepulit - is to be found in Phaedra: 26 "Quis fremitus aures flebilis pepulit meas?" (Sen. Phae. 850) ("What sounds of weeping strike my ears?") ${ }^{27}$ Here too it is used to refer to a disaster. The question in this line is asked by Theseus, who suddenly hears the cries of Phaedra pretending to be bent on committing suicide. ${ }^{28}$

The alarming cries of distress which suddenly reach the ears of Theseus are painful because of their loudness. However, just like the wedding song in $\mathrm{Me}$ $d e a$, these cries are sinister harbingers of an approaching calamity. In both cases, the 'aggressive' sounds are voices of betrayal. In the case of Medea, they announce the fact that Medea has been betrayed by her husband, while in the case of Phaedra they falsely accuse Hippolytus of having wronged Phaedra, i.e. they actually announce the fact that Theseus has been betrayed by his own wife.

In both cases the aggressive sounds which attack the ears of a particular character (Medea, Theseus) announce a calamity that is going to be (or rather is already being) inflicted on that character by a person who is very dear to them, i.e. their husband or wife. The physical 'striking' of the characters' ears by an invisible sonic 'weapon' illustrates the damage which is being inflicted on their minds and souls.

${ }^{25}$ Cf. Ov. Her. 12.137; Perutelli 1989: 102; Trinacity 2007: 70; Trinacity 2014:102.

${ }^{26}$ Compare also: Neque ista, quae te pepulit, armenti gravis / vox est nec usquam territi resonant greges: / immugit aris ignis et trepidant foci. / (Sen. Oed. 381-2) ("That is not the deep call of cattle that strikes your ears, no herds are lowing anywhere in fear: it is the moaning of the fire on the altar, the shuddering of the sacrificial hearth.”) (Trans. Fitch 2004). Anthony Boyle has noticed that - quite interestingly - Seneca has a peculiar tendency to associate the word Hymenaeus with pain and disaster (e.g. Tritonum ab alto cecinit hymenaeum chorus, Sen. Tro. 202). Cf. Keulen 2001: 193.

${ }^{27}$ Trans. Fitch 2002.

${ }^{28}$ Compare: "Quod facinus aures pepulit?" (Sen. HerF. 415) ("What outrage has struck my ears?") (Trans. Fitch 2002). 
Similarly, in Agamemnon the sinister sound of the Greek shields "shakes" or "hits" the ears of the audience:

At licuit dolos versare ut ipsi

fraude sua caderent Pelasgi:

saepe commotae sonuere parmae

tacitumque murmur percussit aures,

ut fremuit male subdolo

parens Pyrrhus Ulixi. (Sen. Ag. 631-6)

And we could have reversed the trick, and made

the Pelasgians fall in their own trap:

many times there were sounds from moving shields,

and a quiet murmur struck our ears,

as Pyrrhus grumbled and chafed

at obeying deceitful Ulysses. ${ }^{29}$

The verb percutio in $A g .634$ - apart from the metaphorical meaning used here by Seneca - also has a number of 'primary' meanings referring to physical actions such as "to pierce" and "to shake".

By contrast, in line 397 Clytemnestra uses the following words to express her joy on learning that Agamemnon has returned to Greece: "Felix ad aures nuntius venit meas." ${ }^{30}$ (Sen. $A g$. 397) ("Happy the news that has reached by ears.") ${ }^{31}$ The good news (nuntius) sounds pleasant and does not attack the ears of the listener (unlike the sounds of a disaster in the passages discussed earlier), but reaches them in an inoffensive (if not friendly) manner by merely "coming" to them. Ag. 397 is also somewhat synaesthetic, as the invisible word is given a kind of metaphorical "body" 32 and the audience can imagine the news gently approaching the ear of the listener.

\section{THE GNASHING OF ENVY'S TEETH}

In Phaedra a quite extraordinary instance of synaesthesia is to be found in the dialogue between Hippolytus and the Nurse, when Hippolytus praises the life of the solitary hunter: "[...] haud illum niger / edaxque livor dente degeneri

\footnotetext{
${ }^{29}$ Trans. Fitch 2004.

${ }^{30}$ It seems that Seneca has intensified Ovid's passage. In his version, the wedding song does not come to the ears, but beats them, causing physical pain. Cf. McGill 2005: 42. Compare: "Ut subito nostras Hymen cantatus ad aures / venit [...]" (Ov. Her. 137-8) ("When, all suddenly, there came to my ears the chant of Hymen, [...]") (Transl. by G. Showerman, Showerman 1914)

${ }^{31}$ Transl. by J. Fitch (Fitch 2004).

${ }^{32}$ Cf. "Vox constituto sera decreto venit." (Sen. Med. 198) ("Your words come too late, my decree is decided.") (Transl. by J. Fitch, Fitch 2002)
} 
petit:" (Sen. Phae. 492-3) (“[...] no black gnawing malice attacks him with its ignoble teeth." ${ }^{33}$ Free of the various misfortunes that may befall ordinary people who live in towns, the hunter is not subject to the wrath of a mob or the whims of a king. Apart from this "exterior" liberty, he also enjoys an inner freedom, as he is prone neither to greed, nor to hatred. One of the worst vices that plague city dwellers is livor, which can be understood to mean either "envy" or "malice".

The primary meaning of livor, however, is physical, as the word denotes blackness, blueness or simply lividity, which is why envy is often depicted as being "livid". Seneca has additionally intensified this meaning - thus making it show through the secondary meaning - by means of the adjective niger. In his tragedies, blackness is often associated with everything hellish, deathly and frightening (e.g. Tro. 21; Ag. 14-15; Oed. 189, 358, 530; Phae. 477, Thy. 665). ${ }^{34}$

Fashioned as a sort of malicious demon, envy in Phaedra is not only black (with a livid hue), but is also voracious (edax). Seneca illustrates this feature by endowing the monster with a "degenerate tooth". ${ }^{35}$ At the same time, he manages to enrich the whole description with 'sound effects', as the alliteration dente degeneri makes the audience actually 'hear' the noise made by the gnashing of envy's teeth. The structure of the ablative dente - together with the immanent alliteration of the dental $t$ in the verb petit - further enhances this sound effect. The motif of teeth itself has been shown to come from Horace. ${ }^{36}$

This example shows just how powerful alliteration can be. By means of this seemingly insignificant device Seneca manages to transform the stereotypical allegory of envy into a fantastic monster that frightens the audience not only with its infernal colour and quite hideous physical appearance, but also with the noise of the ghastly voracious tooth with which it harrows people's souls.

Here again Seneca plays with the primary and secondary meanings of words, as the intertwining of those meanings in the minds of the audience is clearly quite unavoidable. The innate livid 'hue' of envy (livor) is deepened by blackness (niger) and these colours coexist with the sound effects that are obtained by clever imitation of the sound of gnashing by means of the alliteration of dental

${ }^{33}$ Transl. by J. Fitch (Fitch 2002).

${ }^{34}$ This is probably why Michael Coffey and Roland Mayer translate the adjective niger directly as 'evil'. Cf. Coffey and Mayer 1990: 135.

${ }^{35}$ The allegory of toothed envy is not Seneca's invention, but a common image (cf. Ibid.). Compare: "Nec, qui detrectat praesentia, Livor iniquo/ ullum de nostris dente momordit opus." (Ov. Trist. 4.10.123-4) ("Nor has jealousy, that detractor of the present, attacked with malignant tooth any work of mine.") (Trans. Wheeler 1924). See also: Rhet. Her. 4.51.7. More about this topos in: Friedrich 2002: 375. For the topos of livid envy in ancient and modern literature see: Tupper 1917: 551-72.

${ }^{36}$ Cf. Jakobi 1988: 75. Compare: "An si quis atro dente me petiverit" (Hor. Epod. 6.15) ("Well, if someone attacks me with the tooth of malice, am I expected to weep like a child, without retaliating?") (Trans. Rudd 2004). 
consonants (dente degeneri). Thus, at one and the same time the poet appeals to two different senses: to that of sight and - by means of alliteration - to that of hearing.

\section{A MOIST SHROUD}

The motif of blackness plays an important part in yet another passage that may be considered to be an example of Seneca's use of synaesthesia:

Nullum serenis noctibus sidus micat,

sed gravis et ater incubat terris vapor: (Sen. Oed. 46-7)

There are no stars glittering in clear night skies: a heavy black vapour blankets the earth. ${ }^{37}$

Like death (mors atra, line 165) and most of the blood in Oedipus (e.g. lines $140,358,377$ ) - whose vapour (as Susanna Braund has noted) is depicted as black or livid ${ }^{38}$ - the colour of the fog is also black.

At the same time, however, it is also heavy (gravis). Instead of hanging over the ground, it literally lies on it (incubat terris). This expression is similar to one used by Virgil in the Aeneid to refer to night (ponto nox incubat atra, Verg. Aen. 1.89). ${ }^{39}$ Interestingly, apart from the word order, Seneca has changed only two things. In his version, there is land where previously there was sea, while the black night becomes a black fog (ater incubat terris vapor).

Surprisingly, however, despite the fact that Seneca has 'quoted' Virgil's expression in an altered form, he has managed to do so without leaving out any of its elements. Although at first sight there would seem to be no sea in his version, it has a hidden presence, as fog consists of particles of water suspended in the air. Those members of Seneca's audience who were very familiar with the first book of the Aeneid may well have noticed Seneca's trick of turning things upside down, in accordance with Manto's exclamation natura versa est (line 371)..$^{40}$

Like Virgil's night, Seneca's fog behaves like some kind of heavy cloth or even a burial shroud that has been stretched over Thebes - a city that has been polluted by the crimes of murder and incest committed by its king. ${ }^{41}$ This powerful image functions as a metaphor for Oedipus's terrible past, as do the graphically described

\footnotetext{
${ }^{37}$ Trans. Fitch 2004.

${ }^{38} \mathrm{Cf}$. Braund 2016: 68. In this book, Braund (2016: 66-67) also discusses the subject of the "monochromicity" of Oedipus, where - as in Lucan's Pharsalia, blackness definitely dominates over other colours.

${ }^{39}$ Schmitz 1993: 44, n. 105.

${ }^{40}$ Ibid.: 197; Mastronarde 1970: 301. See also: Bettini 1984: 49; Trinacity 1993: 75. Cf. Braund 2016: 48.

${ }^{41}$ Sklenář 2008: 45.
} 
monstrosities in the divination scene.$^{42}$ Ruled by a man who has murdered his own father and slept with his own mother, Thebes is a kingdom that is morally 'dead'. The black shroud of sin therefore symbolizes the sins of Oedipus, while its heavy weight symbolizes the moral 'weight' of those sins.

In these two lines, Seneca has managed to stimulate the audience's ${ }^{43}$ sense of sight by creating a powerful image of black fog that hangs over the ground like a funeral shroud. At the same time, however, he stimulates their sense of touch by making the fog heavy. Not only does he do this directly by means of the adjective gravis, but also - in a more subtle and indirect manner - by using the verb incubat ("lies"), which enhances the imaginary perception of the heaviness of the fog.

The poet also appeals to the sense of hearing:

\section{Nullum serenis noctibus sidus micat}

The alliteration (which is partially collisive, e.g. in noctibus sidus ${ }^{44}$ ) of $s, c$ and $t$ 'illustrates' the twinkling of the stars. At the same time, it produces a peculiar quivering sound, thus stimulating the audience's sense of hearing.

\section{LIQUID LIGHT}

Another interesting synaesthetic technique used by Seneca in his tragedies consists in (metaphorically) depicting elements such as light or fire as if they were liquids. The first example of the use of this technique is to be found in Phaedra:

quid ille rebus lumen infundens suum,

matris parens? [...] (Sen. Phae. 154-5)

what of him who pours his light on the world,

your mother's father? ${ }^{45}$

This rhetorical question refers to Titan, i.e. the god of the sun and also Phaedra's divine ancestor. He is the source of light, which he literally pours over all things below (rebus lumen infundens suum).

\footnotetext{
${ }^{42}$ Braund 2016: 46-51. For the monstrosity of the main hero of Oedipus see also: Williams 1996: 251 .

${ }^{43}$ However, although the sound effects which are present in Seneca's tragedies can of course also be perceived by 'mere' readers (and some scholars have recently unearthed convincing evidence of the dramatic potential of these plays, cf. Kohn 2012), the question as to whether the plays ever had an audience in the proper meaning of the word still remains open.

${ }^{44}$ For collisive alliteration see: Highet 1974.

${ }^{45}$ Trans. Fitch 2002.
} 
The participle infundens is a composite of the particle in and the stem fundere. The same stem forms the participle perfusus in Med. 100, which is used metaphorically in reference to Creusa's blush. Because of their primary meaning (infundo means "to pour in" or "to pour into", while perfundo means "to pour / sprinkle all over"), both participles therefore bring about strong associations with the action of pouring liquid substances.

Seneca also alliterates the liquid consonants, thus intensifying the effect: quid ille rebus lumen infundens suum. Thanks to this simple, yet efficient device, Seneca's depiction of the shining sun in the passage quoted above appeals to more than just one of the senses as the audience is encouraged to imagine not only the bright colour of Titan's rays, but also to 'feel' the 'liquid' warmth of sunlight being poured all over the earth. ${ }^{46}$

The next place where the poet uses this technique is also to be found in Medea:

Sic face tristem pallida lucem

funde per auras, [...] (Sen. Med. 793-4)

Pour dismal light with this pallid glare through the atmosphere $;{ }^{47}$

These lines form part of Medea's long monologue, which is at the same time a prayer - or rather an incantation - to the gods of the Underworld (lines 740848). Anthony Boyle has called this monologue Medea's "black mass". ${ }^{48}$

Here again, Seneca uses the same metaphorical kind of synaesthesia. Medea wishes that the "sad" light of Dictynna's torch (tristem ... lucem) be literally "poured through the air". Such a depiction appeals not only to the audience's sense of sight, but also to their sense of touch as the sensory imagination of the listener or reader can easily 'perceive' the hue, the warmth and the density of the light.

\section{A SWEET WHISPER}

The synaesthetic appeal to the sense of taste that is present in the primary meaning of the word ostrum in Med. 99 also occurs in the following seemingly stereotypical passage of Phaedra: [...] sive per flores novos / fugiente dulcis murmurat rivo sonus (Phae. 513-14) (or through fresh flowers a sweet sound murmurs from a fleeting brook). ${ }^{49}$ These lines form part of Hippolytus's monologue, which is the young hero's response to the words of the Nurse, who encourages him to abandon the life of a solitary hunter for that of a city youth. ${ }^{50}$

\footnotetext{
${ }^{46}$ Coffey and Mayer also translate rebus as 'the world'. Cf. Coffey and Mayer (1990: 106).

${ }^{47}$ Trans. Fitch 2002.

${ }^{48}$ Cf. Boyle 2014: c.

${ }^{49}$ Trans. Fitch 2002.

${ }^{50}$ For the differences of outlook between Hippolytus and the Nurse see: Gunderson 2015: 114. Cf. Mayer 2002: 38-9.
} 
Hippolytus portrays the woods as a kind of earthly paradise. As he praises all its delights, he seems to 'see' and 'feel' them in his imagination. Among the main pleasures of such an existence he numbers walking along river banks (lines 10-11), sleeping on grass (lines 11-12) and being able to satisfy his hunger with apples shaken down from trees and berries picked from bushes (lines 15-16).

However, one of the most pleasant sensations involves listening to the sound of a brook running alongside young flowers. The adjective dulcis - used here in reference to the whispering of the water - is strongly connected with the sense of taste, as its primary meaning is purely 'physiological'. The same adjective appears in Oedipus - also in reference to the word sonus: qui saxa dulci traxit Amphion sono (Oed. 612) (whose sweet sound once shifted stones.) ${ }^{51}$ The expression dulcis sonus in the line above refers to the music of Amphion's lyre. ${ }^{52}$

In Phae. 513-14, however, it seems that the poet goes far beyond the commonplace of pleasant, "sweet" sound, as he makes the most of the sonorous potential of words. The verb murmuro - itself already onomatopoeic - evokes the delicate whisper of the mountain brook, while the alliteration of the spirant $s$ in line 513 imitates that whisper (sive per flores novos). This sigmatism functions as a kind of 'soundtrack' to the declamation.

In these lines, Seneca appeals to three senses at the same time: the primary, non-metaphorical meaning of the adjective dulcis is "sweet" in the physical sense, and so this word, though metaphorically referring to sound, still appeals to the audience's sense of taste. Together with the sigmatic alliteration of $s$, the onomatopoeic verb murmuro stimulates the sense of hearing. In addition, the vivid depiction of the brook stimulates the visual imagination of the audience.

\section{CONCLUSION}

The examples of poetic synaesthesia that have been discussed in this article show quite clearly that Seneca was not only familiar with this technique, but that he used it to perfection. We have also seen that Senecan synaesthesia is not limited to a simple figure of speech consisting in describing one sense in terms of another (i.e. synaesthesia sensu stricto), but that it should be treated as synaesthesia sensu largo, where various literary devices are used in order to appeal to more than one of the senses at a time.

Our analysis has also shown that in order to stimulate the audience's sense of hearing, Seneca sometimes achieves (or simply intensifies) the effect of auditory

\footnotetext{
${ }^{51}$ Trans. Fitch 2004.

${ }^{52}$ Cf. Keulen 2001: 246.
} 
synaesthesia by means of alliteration, often making the most of the natural sonorous potential of words - reduplication, immanent sigmatism and any other feature that can be used for the purposes of synaesthesia.

Apart from alliteration, Seneca very often uses polysemy in order to achieve a synaesthetic effect. Skilfully playing with primary, secondary, 'physical' and metaphorical meanings of words, he creates the sensory enhancement of a particular meaning, as in the case of the noun livor or the stem of fundere.

The range of techniques which Seneca uses in order to appeal to the audience's senses is quite remarkable. To some extent, the poet must have owed this to his privileged position as the son and pupil of a famous rhetorician whose acquaintances happened to be the best poets. However, all the literary devices he mastered would have been to little avail had he not had an extraordinary imagination which allowed him to trigger multisensory experiences on the part of the audience using words alone.

\section{BIBLIOGRAPHY}

Primary sources

Braund 2016: S. Braund, Seneca: Oedipus, London-New York, 2016.

Boyle 2014: A. J. Boyle (ed. with a comm.), Seneca, Medea, Oxford 2014.

Coffey and Mayer 1990: M. Coffey and R. Mayer (eds.), Seneca, Phaedra, Cambridge, 1990.

Fitch 2002: J. Fitch (ed. with a transl.), Seneca, Tragedies, Volume I: Hercules, Trojan Women, Phoenician Women, Medea, Phaedra, Cambridge MA, 2002.

Fitch 2004: J. Fitch (ed. and trans.), Seneca. Tragedies, Volume II: Oedipus, Agamemnon, Thyestes, Hercules on Oeta, Octavia, Cambridge MA, 2004.

Keulen 2001: A. J. Keulen (ed. with a comm.), L. Annaeus Seneca, Troades, Leiden-Boston-Köln, 2001.

Mayer 2002: R. Mayer, Seneca: Phaedra, London 2002.

Rudd 2004: N. Rudd (trans.), Horace. Odes and Epodes, Cambridge MA 2004.

Rushton Fairclough 1918: H. Rushton Fairclough, Virgil, Aeneid: Books 7-12. Appendix Vergiliana, Cambridge MA, 1918.

Showerman 1914: G. Showerman (trans.), Ovid, Heroides. Amores, Cambridge MA, 1914.

Wheeler 1924: A. L. Wheeler (transl.), Ovid, Tristia. Ex Ponto, Cambridge MA, 1924.

Secondary sources

Baertschi 2016: M. Baertschi, "Epic Elements in Senecan Tragedy," in: G. W. M. Harrison (ed.), Brill's Companion to Roman Tragedy, Boston-Leiden 2016, 171-95.

Bellandi 2010: F. Bellandi, "La sposa, la porpora e le luci dell'alba (a proposito di Seneca, Medea 99-101)," Hermes 138 (2010), 487-93.

Bettini 1984: M. Bettini, "Lettura divinatoria di un incesto (Seneca Oed. 366 ss.)," MD 12 (1984), $145-59$.

Bradley 2013: M. Bradley, Colour as a Synaesthetic Experience in Antiquity, in: S. Butler and A. Purves (eds.), Synesthesia and the Ancient Senses, Oxford-London 2013, 127-40.

Bradley 2016: M. Bradley (ed.), Smell and the Ancient Senses, Oxford 2016.

Butler and Purves 2013: S. Butler and A. Purves (eds.), Synesthesia and the Ancient Senses, Oxford-London 2013. 
Friedrich 2002: A. Friedrich, Das Symposium der "XII sapientes". Kommentar und Verfasserfrage, Berlin-New York 2002.

Gunderson 2015: E. Gunderson, The Sublime Seneca. Ethics, Literature, Metaphysics, Cambridge 2015.

Highet 1974: G. Highet, “Consonant Clashes in Latin Poetry,” CPh 69 (1974), 178-85.

Jakobi 1988: R. Jakobi, Der Einfluss Ovids auf den Tragiker Seneca, Berlin-New York 1988.

Kent 1910: R. G. Kent, "Haec ubi dicta agrestem pepulere, Horace, Sat. II, 6, 97-98," TAPhA 41 (1910), xlv-vi.

Kohn 2012: T. D. Kohn, The Dramaturgy of Senecan Tragedy, Ann Arbor 2012.

Mastronarde 1970: D. Mastronarde, "Seneca's Oedipus: The Drama in the Word," TAPhA 101 (1970), 291-315.

McCabe 1993: R. A. McCabe, Incest, Drama and Nature's Law 1550-1700, Cambridge 1993.

McGill 2005: S. McGill, Virgil Recomposed. The Mythological and Secular Centos in Antiquity, Oxford 2005.

Perutelli 1989: A. Perutelli, "Il primo coro della Medea di Seneca," MD 23 (1989), 99-117.

Rees 1994: R. Rees, “Common Sense in Catullus 64," AJPh 115 (1994), 75-88.

Schmitz 1993: Ch. Schmitz, Die Kosmische Dimension in den Tragödien Senecas, Berlin-New York 1993.

Segal 1977: Ch. Segal, "Synaesthesia in Sophocles," ICS 2 (1977), 88-96.

Sklenář 2008: R. Sklenáŕ, "Oedipus 980-94: How Stoic a Chorus?," CJ 103 (2008), 183-94.

Slaney 2016: E. Slaney, The Senecan Aesthetic. A Performance History, Oxford 2016.

Squire 2016: M. Squire (ed.), Sight and the Ancient Senses, Oxford 2016.

Stevens 2008: B. Stevens, "The Scent of Language and Social Synaesthesia at Rome," $C W 101$ (2008), 159-71.

Trinacity 2007: Ch. V. Trinacity, "Seneca's Heroides: Elegy in Seneca's Medea," CJ 103 (2007), 63-78.

Trinacity 2014: Ch. V. Trinacity, Senecan Tragedy and the Reception of Augustan Poetry, OxfordNew York 2014.

Tupper 1917: F. Tupper, “The Envy Theme in Prologues and Epilogues,” The Journal of English and Germanic Philology 16 (1917), 551-72.

Volk 2013: K. Volk, "Manilius' Cosmos of the Senses," in: S. Butler and A. Purves (eds.), Synesthesia and the Ancient Senses, Oxford-London 2013, 103-114.

Walter 2013: B. Walter, "Reading Death and the Senses in Lucan and Lucretius," in: S. Butler and A. Purves (eds.), Synesthesia and the Ancient Senses, Oxford-London 2013, 115-125.

Williams 1996: S. Williams, The Function of the Monster in Mediaeval Thought and Literature, Montreal and Kingston 1996.

Wilson 2010: M. Wilson, Rhetoric and the Younger Seneca, in: W. Dominik and J. Hall (eds.), A Companion to Roman Rhetoric, Oxford 2010, 425-38.

\section{SENECA AND SYNAESTHESIA. THE SENSORY ASPECT OF THE TRAGEDIES}

Sum mary

The present article discusses the poetic means which Seneca uses in order to achieve the effect of synaesthesia in his tragedies. An analysis of chosen examples reveals that he attempts to stimulate the audience's sensory imagination with the aid of various techniques which he often combines. Simple, yet skilfully used devices such as alliteration or polysemy often help the poet to intensify an effect or to add another in order to make the most of the natural potential of descriptive words. 